\title{
Absence of Serological Relationship Between the Marburg Virus and Some Arboviruses
}

\author{
Dr. J. Casals
}

It can be stated with hardly a doubt that the serological characterization of the Marburg agent is as complete as that of any infectious agent that has been investigated in recent years. The result of the investigation can be stated simply: Marburg virus is an agent sui generis, serologically distinct and unrelated to any of perhaps close to 200 microorganisms with which it has been compared. In a way this could end the present paper, particularly since a sizable part of the results directed towards establishing the antigenic characteristics of the agent have already been reported in publications from several laboratories.

There are some reasons, however, that justify the present communication :

a) An attempt to bring together all serological examinations carried out, with particular stress on viral studies and on the work done at Yale Arbovirus Research Unit-Rockefeller Laboratories.

b) A description of the phases through which the emphasis on the characterization of this agent has gone, from the very early days of the onset of the outbreak in August, 1967, to the present day.

c) A description of recent work, unreported, comparing the Marburg agent with other viruses, some of which bear certain similarities to it, for example in the type of illness caused by them.

\section{a) Summary of Serological Studies}

Other participants in this Symposium have or will report on studies dealing with the comparison of the Marburg agent with bacterial microorganisms, which early set this agent apart from a number of bacteriae (Schizomycetes), including leptospirae and rickettsiae. We will report here only on virological studies, mainly by the staff of YARU; but also, for the sake of completeness, I will mention studies done elsewhere, especially when done with viruses not available in our laboratory.

Owing to the extreme danger at first attached to work with the Marburg agent and to the lack in our organization of isolation facilities comparable to those of other laboratories, added to the fact that attempts to isolate and, later, propagate the agent were already under way in other laboratories, the decision was made that no work connected with isolation or propagation of the agent would be done at YARU. Consequently the work reported here consists almost exclusively of examination of the reaction between sera from patients and guinea pigs and viral antigens, excluding the Marburg antigen; in some recent tests, an inactivated Marburg virus antigen has been tested against various immune sera. 
The sera and antigen pertaining to the Marburg infection received and, for the most part, studied at YARU are listed in Table 1.

Table 1. Materials connected with Marburg virus infection or inoculation used in tests at $Y A R U$

Sera

Human, supplied by Prof. R. Siegert and Dr. F. Lehmann-Grube

$\begin{array}{lll}\text { Patient } & \text { Onset } & \text { Date of Sample } \\ \text { DIE } & \text { Aug. 14 } & \text { Aug. 30, Sept. 9 } \\ \text { FRI } & \text { Aug. 8 } & \text { Aug. 21 } \\ \text { HAN } & \text { Aug. 16 } & \text { Sept. 9 } \\ \text { HIL } & \text { Aug. 14 } & \text { Aug. 30, Sept. 9 } \\ \text { KLI } & \text { Aug. 14 } & \text { Aug. 19, Aug. 24, Sept. 9 } \\ \text { KRA } & \text { Aug. 14 } & \text { Aug. 24, Sept. 9 } \\ \text { MUE } & \text { Aug. 16 } & \text { Sept. 9 }\end{array}$

Guinea pig

Supplied by Drs. C. E. G. Smith and D. I. H. Simpson, M.R.E.

Nos. 3699, 3700, 3701, and 3702.

Bled 19 days after inoculation of infectious material, while convalescing; homologous complement-fixing titers, $1: 32-1: 64$.

Nos. 1, 2, 3, and 4 .

Two immunized and two hyperimmunized with the established Marburg agent; CF titers, $1: 128$.

Supplied by Dr. F. A. Murphy, N.C.D.C.

No. 15, immunized with the Marburg agent; CF titer, $1: 128$.

Antigens

Supplied by Dr. F. A. Murphy, N.C.D.C.

AGMA (Marburg), guinea pig liver, inactivated by bpl; CF titer, $1: 128$. Control for above, normal guinea pig liver.

In Table 2 are listed the arbovirus antigens and a few non-arbovirus ones employed in the tests. Some of the viruses that appear in the ungrouped class have now been placed in antigenic groups; but this is immaterial for the present report. One hundred and thirteen viruses are listed; however, considering group relationships and the manner in which the tests were conducted, it is fair to assume that these viruses represent an additional 50 arboviruses that belong to groups and are closely related by CF or HI to some of the listed agents.

In general outline the tests with sera listed in Table 1, and with antigens in Table 2 were done as follows:

1. Hemagglutination-inhibition test. The following sera were tested: from 6 patients bled on September 9, 1967, 24-26 days from onset of their illness and from 2 of the same patients bled on August 30, or 16 days from onset. Also were tested sera from 4 guinea pigs, convalescing 19 days from inoculation. While at the time that we carried out the tests the immune state of these sera was unknown owing to lack of an antigen for the Marburg agent, it was subsequently determined by Drs. Smith and Simpson that CF antibodies were present in the sera. Hence, the negative results obtained at YARU could be considered valid. 
Table 2. Arbovirus antigens used in tests with sera from Marburg infection patients and from guinea pigs infected or immunized with the virus

Group Viruses

A

B

Bunyamwera

Bwamba

$\mathrm{C}$

California

Guama

Simbu

Bakau

Dugbe

EHD

Kaisodi

Kemerovo

Koongol

Mossuril

Nyando

Phlebotomus

Piry

Quaranfil

Tacaribe

Turlock

VSV

Ungrouped Non-Arbovirus Herpes, LCM, NDV, poxvirus, rabies, mumps ${ }^{1}, \mathrm{SHF}^{4}$ O'nyong-nyong, Semliki, Sindbis, VEE', WEE. yellow fever, Zika.

Bwamba

Caraparu, Marituba ${ }^{1}$, Oriboca

Tahyna, Lumbo

Catu

Akabane, Ingwavuma, Sathuprei, Simbu, Yaba 7

Ketapang

Dugbe, Ganjam

EHD-New Jersey

Kaisodi, Lanjan

Chenuda, Kemerovo

Koongol, Wongal

Mossuril

Nyando

Neapolitan, Sicilian

Chandipura, Piry

Johnston Atoll, Quaranfil 10411' ${ }^{1}$, Maru 10886 ${ }^{1}$, Maru $12056^{1}$

Umbre

Cocal, VSV-Ind, VSV-N J
Aura ${ }^{1}$, Chikungunya, EEE ${ }^{1}$, Mayaro ${ }^{1}$, Middleburg, Ndumu,

Banzi, Bussuquara ${ }^{1}$, dengues 1, 2, 3, and 4, IbAr8646, Ilheus ${ }^{1}$, $\mathrm{JBE}^{2}, \mathrm{KFD}$, Langat ${ }^{2}$, Louping ill, Ntaya, OHF, Powassan, RSSE, Spondweni, SLE ${ }^{1}, T_{e}$ busu$^{2}$, Uganda S, Wesselsbron, West Nile,

Batai, Bunyamwera, Cache Valley ${ }^{1}$, Germiston, Ilesha.

Amapari, Junin, Machupo ${ }^{1}$, Pichinde, Tacaribe, Tamiami, Maru

Bhanja, CTF, Congo, Flanders, Hart Park, IbAr2709, IG 5139, IG 5287, IG 7481, IG 633970, Kern Canyon, Kowanjama, Lagos bat, Mapputta, Mt. Elgon bat, Nyamanini, Ogunpa, Pinn., Rift valley fever $^{3}$, SA An 4511, SA Ar 136, Tataguine, Thogoto, TR 5843, Uukuniemi, Wad Medani, Wanowrie, Witwatersrand, Yaba 1, and

Drs. K. M. Johnson and P. A. WebB.

2 Drs. C. E. G. Smith and D. I. H. Simpson.

3 Dr. R. Costlow.

4 Drs. A. Shelokov and N. Tauraso.

The above sera were tested in 2-fold dilutions beginning at $1: 10$ against 8 units of antigen; the method was practically the same at the MRE (Drs. Smith and Simpson) as at YARU. The antigens used were: Group A, Chikungunya, O'nyongnyong, Semliki, and Sindbis; Group B, dengue 1 and 2, West Nile, Spondweni, Banzi, Wesselsbron, Zika, yellow fever, Ntaya, RSSE, IbAn8646, JBE, Tembusu, Langat, and Louping ill; others, Bunyamwera, Germiston, Ilesha, Bwamba, Tahyna, and IbAn 2709.

2. Completement-fixation test. The sera from the 7 patients listed, including one from the first person to come down in the outbreak, were tested at YARU; the same specimens, or others close in time to them, were subsequently tested at 
MRE, once they had prepared an antigen, and found to have CF antibody titers between $1: 16$ and $1: 64$, as stated above. The general procedure followed was to test each serum in 4 two-fold dilutions, beginning at either $1: 4$ or $1: 8$, against each antigen in dilutions $1: 4,1: 8$, and $1: 16$, which represented from 4 to 64 or more antigenic units. As far as it has been ascertained, the same procedure was followed at Middle America Research Unit, by Drs. Johnson and WebB.

The guinea pig sera were, in addition, tested against selected antigens, as described later.

The result of this considerable number of tests was invariably negative, with the exception of that given by sera from patients HIL which reacted at dilutions $1: 4$ or $1: 8$ with antigens for herpes and RSSE and DIE which reacted with a titer of $1: 4$ or $1: 8$ with herpes; these antibodies were considered unrelated to the current disease.

The conclusion that we reached and reported at the time, October 4, 1967, was that while negative results are not as definitive as positive evidence, it was our opinion that it was most unlikely that any of the viruses used in our survey was responsible for the illness of the 6 patients; this conclusion is still valid today.

\section{b) Emphasis on Possible Particular Etiologies of the Marburg Infection}

In the early days following the onset of the outbreak, the association between human illness and blood or tissues from African monkeys led to consider the possibility of an etiological agent originating in equatorial Africa; observation in postmortem specimens of hepatic lesions or formations reminiscent of Councilman bodies aroused the suspicion that the disease might be yellow fever, with humans infected through an aerosol. Rift valley fever was also mentioned in this connection.

By the 30th of August, 1967, yellow fever was no lon ger considered (at that time, tests at YARU with the first serum available, FRI, showed lack of positive reaction with yellow fever and other Group B antigens). The definite hemorrhagic manifestations both clinical and pathological, led the attending physicians to entertain the possibility of an hemorrhagic fever, probably caused by an arbovirus, since leptospiral infection did not appear to be at work.

The early reported results on the possible arboviral etiology of this hemorrhagic fever were somewhat conflicting. A laboratory reported the presence of Group B antibodies (against West Nile and Wesselsbron) "compatible with a Group B infection", in one of the patients. Another reported antibodies against Omsk hemorrhagic fever in 5 patients, with an increase in titer in one of them, leading to "thinking of the possibility that the responsible agent belongs in the TBE subgroup, closer to OHF than to the others". Another laboratory, somewhat later, observed questionable antibodies in one of the patients against some of the newly discovered viruses of the Tacaribe Group.

While there may have been clinical and pathological similarities between the Marburg virus infection and the viral hemorrhagic fevers - both of Group B and outside - the serological evidence gathered at YARU at the time did not support the theory of a serological connection between the disease and any of the Tacaribe 
Group agents available or with the hemorrhagic fevers of the TBE complex; a summary of the results is shown in Table 3.

Table 3. Complement-fixation test

Human convalescent and guinea pig immune sera, Marburg virus

Tacaribe group and 2 group $B$ antigens

\begin{tabular}{|c|c|c|c|c|c|c|c|c|c|c|c|c|c|c|}
\hline \multirow{4}{*}{$\begin{array}{l}\text { Antigen } \\
\text { Reciprocal of } \\
\text { Titer }\end{array}$} & & \multicolumn{13}{|c|}{$\underline{\text { Serum }}$} \\
\hline & & \multirow{2}{*}{\multicolumn{3}{|c|}{$\begin{array}{l}\text { Man, Aug. 30, } \\
1967\end{array}$}} & \multirow{2}{*}{\multicolumn{6}{|c|}{ Man, Sept. 9, 1967}} & \multicolumn{4}{|c|}{ Guinea Pig } \\
\hline & & & & & & & & & & & \multirow{2}{*}{-99} & \multirow[t]{2}{*}{00} & \multirow[t]{2}{*}{01} & \multirow[t]{2}{*}{02} \\
\hline & & DIE & HIL & DRE & DIE & HIL & KRA & MUI & $\mathrm{HA}$ & v KLI & & & & \\
\hline Amapari & 256 & 0 & 0 & & & & 0,0 & & & 0 & 0 & 0 & 0 & 0 \\
\hline Junin & 256 & 0 & 0,0 & 0 & 0 & 0 & 0,0 & 0 & 0 & 0,0 & 0 & 0 & 0 & 0 \\
\hline Machupo & & & 0 & 0 & & & 0 & & & 0 & & & & \\
\hline Pichinde & 16 & 0 & 0 & & & & & & & & 0 & 0 & 0 & 0 \\
\hline Tacaribe & 256 & 0 & 0,0 & 0 & & & 0,0 & & & 0,0 & 0 & 0 & 0 & 0 \\
\hline Tamiami & 256 & 0 & 0,0 & 0 & & & 0,0 & & & 0,0 & 0 & 0 & 0 & 0 \\
\hline Maru 12056 & & & 0 & 0 & & & 0 & & & 0 & & & & \\
\hline Maru 10411 & & & 0 & 0 & & & 0 & & & 0 & & & & \\
\hline Maru 10886 & & & & $8 ?$ & & & $16 ?$ & & & $16 ?$ & & & & \\
\hline KFD & 256 & 0 & 0 & & 0 & 0 & 0 & 0 & 0 & 0 & & & & \\
\hline Omsk HF & 512 & 0 & 0 & & 0 & 0 & 0 & 0 & 0 & 0 & & & & \\
\hline Marburg & & 32 & & 32 & 32 & & $\begin{array}{r}16- \\
64\end{array}$ & $\begin{array}{r}16- \\
64\end{array}$ & & & $\begin{array}{r}32- \\
64\end{array}$ & $\begin{array}{r}32- \\
64\end{array}$ & $\begin{array}{r}32- \\
64\end{array}$ & $\begin{array}{r}32 \\
64\end{array}$ \\
\hline
\end{tabular}

Reciprocal of serum titers; 0 , no fixation at dilution $1: 4$ or $1: 8$.

When duplicate results appear one was by Dr. K. M. JoHnson, who also performed all the tests with serum DRE and with antigens Machupo and Marus.

As can be seen in the table, at no time was there in our hands a positive reaction between human or guinea pig sera, known subsequently to be positive by CF against the Marburg agent, and any of the Tacaribe Group agents or the antigens from the TBE complex. The positive reaction given by 3 sera and antigen MARU 10886, first reported by Drs. JoHnson and WEBB, were subsequently considered by the same workers to have been non-specific.

In October, 1967, Professor Siegert first described the morphology, now familiar, of the Marburg agent, later confirmed at the NCDC, Atlanta. Except for its dimensions, Marburg virus resembled, in its inner structure and configuration, the viruses of Vesicular Stomatitis Group. Based on its morphology, the working hypothesis was made that possibly Marburg virus was a rhabdovirus and that it might be serologically related to the VSV group. Among our early tests (see Table 4), no positive reaction was observed between the sera from the 6 patients and 2 antigens (VSV-Indiana and Chandipura). The tests were later extended to include VSV-New Jersey and Hart Park antigens with the serum of a patient; nor was there any positive reaction between 3 guinea pig sera from MRE and 5 antigens of the group. Recently, and as the group has expanded to include other agents, a comprehensive study has been done by Dr. R. E. SHope, YARU, whose results we quote with his kind permission. As Table 4 shows, no reaction has occurred between the serum from guinea pig Nr. 15 and any of the antigens; nor be- 
tween antisera for each virus of the VSV group and Marburg antigen. The conclusion at this time is that while Marburg virus may be a rhabdovirus, there is no evidence that it is a member of the VSV antigenic group of arboviruses.

Table 4. Complement - fixation test

Human convalescent and guinea pig immune sera, Marburg virus Rhabdovirus antigens

\begin{tabular}{|c|c|c|c|c|c|c|c|c|c|c|}
\hline \multirow[t]{3}{*}{ Antigen } & \multicolumn{10}{|c|}{ Serum } \\
\hline & \multicolumn{6}{|c|}{ Man, Sept. 9, 1967} & \multicolumn{4}{|c|}{ Guinea Pig } \\
\hline & DIE & HIL & KRA & MUE & $\mathrm{HAN}$ & KLI & 2 & 3 & 4 & 15 \\
\hline VSV-N J & & & 0 & & & & 0 & 0 & 0 & 0 \\
\hline VSV-Ind & 0 & 0 & 0 & 0 & 0 & 0 & 0 & 0 & 0 & 0 \\
\hline Cocal & & & & & & & 0 & 0 & 0 & 0 \\
\hline Piry & & & & & & & & & & 0 \\
\hline Chandipura & 0 & 0 & 0 & 0 & 0 & 0 & & & & 0 \\
\hline Hart Park & & & 0 & & & & 0 & 0 & 0 & 0 \\
\hline Flanders & & & & & & & & & & 0 \\
\hline Rabies & & & & & & & 0 & 0 & 0 & 0 \\
\hline Mt. Elgon bat & & & & & & & & & & 0 \\
\hline Kern Canyon & & & & & & & & & & 0 \\
\hline Marburg & $32 *$ & & $16-64 *$ & $16-64 *$ & & & 64 & 64-128* & 64-128* & 128 \\
\hline
\end{tabular}

Reciprocal of serum titers; 0 , no fixation at dilution $1: 4$.

Guinea pig sera No. 2, 3, and 4 supplied by Dr. D. I. H. Simpson; No. 15 by Dr. F. A. Murphy.

* Titers supplied by Drs. D. I. H. Simpson and C. E. G. Smith;

Results with guinea pig No. 15 supplied by Dr. R. E. SHope; in a reciprocal test with sera for all above listed viruses against Marburg antigen, he obtained only negative reactions.

\section{c) Recent Studies Involving Marburg Virus}

Certain developments have occurred in recent months that have re-awakened our interest in continuing an examination of relationships between the Marburg agent and other viruses. CHumakov and associates have succeeded lately in isolating in mice the causative virus of Crimean hemorrhagic fever and we have shown that this virus is similar, if not identical, antigenically to Congo virus; the latter has been known to be present in equatorial Africa from Uganda to Nigeria. Still more recently a hemorrhagic disease has been observed by FRAME and associates, which at this writing has affected 3 American medical missionary nurses, stationed in NE Nigeria; of these, 2 died and the third recovered after a long and serious illness. An additional as yet unreported illness (with virus isolation) has occurred in a staff member (J. C.) of YARU. From the early sera from all 3, Dr. BUCKLEY, YARU, has isolated a virus by inoculation of African green monkey kidney cells cultures (Vero cells). This agent is currently under investigation; serologically, it has been found distantly related to LCM and Tacaribe Group viruses of all agents with which it has so far been compared. We have succeeded in developing a CF system with this agent, called here Pinn., and studies carried out with it, Marburg and other systems are summarized in Table 5. 
Table 5. Complement-fixation test

Study of relationships among viral hemorrhagic fevers

\begin{tabular}{|c|c|c|c|c|c|c|c|c|c|c|c|c|c|}
\hline \multirow[t]{2}{*}{$\begin{array}{l}\text { Antigen, } \\
\text { titer }\end{array}$} & \multicolumn{3}{|c|}{$\begin{array}{l}\text { Serum } \\
\text { Marburg } \\
\end{array}$} & \multirow{2}{*}{$\begin{array}{l}\text { Con } \\
\text { Mou. }\end{array}$} & \multicolumn{2}{|c|}{ Pinn. } & \multirow[t]{2}{*}{ SHF } & \multirow[t]{2}{*}{ NSD } & \multirow[t]{2}{*}{$\mathrm{RVF}$} & EHD & \multirow{2}{*}{$\begin{array}{l}\mathrm{KHF} \\
\text { Man }\end{array}$} & \multirow{2}{*}{$\begin{array}{l}\text { G.B. } \\
\text { Mou. }\end{array}$} & \multirow{2}{*}{$\begin{array}{l}\text { G.TAC } \\
\text { Mou. }\end{array}$} \\
\hline & Gp2 & Gp15 & 5 Man & & Man & Mou. & & & & Mou. & & & \\
\hline $\begin{array}{r}\text { Marburg } \\
1: 128\end{array}$ & & & $32-$ & & & & & & & & & & \\
\hline $\begin{array}{l}1: 128 \\
\text { Congo }\end{array}$ & 64 & 128 & 64 & $\begin{array}{c}0 \\
128-\end{array}$ & 0 & & 0 & 0 & 0 & 0 & 0 & 0 & 0 \\
\hline $\begin{array}{c}1: 1024 \\
\text { Pinn }\end{array}$ & & 0 & 0 & 256 & 0 & 0 & 0 & 0 & 0 & 0 & & 0 & 0 \\
\hline $\begin{array}{l}\text { Pinn } \\
\quad 1: 16\end{array}$ & 0 & & & 0 & 128 & 128 & 0 & 0 & 0 & 0 & 0 & 0 & 0 \\
\hline SHF & & & & & & & & & & & & & \\
\hline $\begin{array}{l}1: 256 \\
\text { NSD }\end{array}$ & & & $0 * * *$ & 0 & 0 & & 256 & $\begin{array}{c}0 \\
128^{*}\end{array}$ & 0 & 0 & $0 * * *$ & $0^{* * *}$ & $0 * * *$ \\
\hline $\begin{array}{l}\text { RVF } \\
\text { EHD-N I }\end{array}$ & & & & & & & & & $256 * *$ & & & & \\
\hline $\begin{array}{c}1: 16 \\
\text { Group B }\end{array}$ & & & 0 & 0 & & 0 & 0 & & & 16 & & & \\
\hline $1: 128-512$ & & 0 & 0 & 0 & 0 & & 0 & 0 & 0 & 0 & 0 & Pos & 0 \\
\hline $\begin{array}{l}\text { Tacaribe } \mathrm{g} . \\
1: 32-512\end{array}$ & & & 0 & 0 & 0 & & 0 & & & 0 & 0 & 0 & Pos \\
\hline
\end{tabular}

SHF, simian hemorrhagic fever; NSD, Nairobi sheep disease; RVF, Rift Valley fever; EHD-N J, epizootic hemorrhagic deer disease, New Jersey type; KHF, Korean hemorrhagic fever.

Group B antigens include: Omsk HF, KFD and dengues 1-4; Tacaribe group include: Amapari, Junin, Machupo, Pichinde, Tacaribe, and Tamiami.

Reciprocal of serum titers; 0 , no fixation at $1: 4$ or $1: 8$.

* Titer given by Dr. R. West, E.A.V.R.I.

** Titer given by Dr. Richard Costlow.

*** Results supplied by Drs. N. Tauraso and A. Shelokov.

The observations with the viruses listed in Table 5 are, at the moment, still incomplete. With some agents, Nairobi sheep disease and Rift Valley Fever, no antigens are available owing to safety restrictions; with another system, Korean hemorrhagic fever, no virus has as yet been propagated in laboratory experimental hosts, therefore, sera from survivors can only be assumed to have antibodies. The results with Simian hemorrhagic fever will be discussed more extensively by Drs. Tauraso and Shelokov later in the Symposium. The net result of these investigations is that the 10 types of hemorrhagic fevers shown in the table are antigenically unrelated.

Conclusion. The result of an extensive search for antigenic relationships between the Marburg virus and a large number of arboviruses, and a few viruses not of that set, can be summarized with the sentence with which I opened this paper. Marburg virus is an antigenically distinct virus, unrelated to any with which it has been so far compared. 